\title{
Effort to Prevent COVID-19 STIKES Samarinda (STIKSAM) by Distributing Hand Sanitizer in Air Hitam Village of Samarinda City Upaya Pencegahan COVID-19 STIKES Samarinda (STIKSAM) dengan Menyalurkan Hand Sanitizer di Kelurahan Air Hitam Kota Samarinda
}

\author{
Eka Siswanto Syamsul*, Supomo, \& Achmad Kadri Ansyori \\ Sekolah Tinggi Ilmu Kesehatan Samarinda, Indonesia
}

\begin{abstract}
Due to the COVID-19 pandemic outbreak, the availability of handwashing products in Samarinda City has become a rare item. The purpose of this activity is to prevent COVID-19 through the use of Hand Sanitizer. This method in this service includes several stages, namely preparation that includes the preparation of tools and materials, the production process with the stages of mixing materials into hand sanitizer products, and the packaging process that is inserting the finished hand sanitizer into small bottles measuring $20 \mathrm{ml}, 100 \mathrm{ml}$ and Container $5 \mathrm{~L}$, as well as labelling the brand hand sanitizer, and subsequently the distribution process in RT 27, 28, 29 and 30 Black Water Village. Civitas Akademika STIKES Samarinda (STIKSAM) and Ikatan Keluarga Alumni (IKA STIKSAM) make hand sanitizer in accordance with WHO regulations, hand sanitizer distribution process in rt 27, RT 28, RT 29 and RT 30 Black Water Village and COVID-19 referral hospital (AW Hospital. Sjahranie and I.A. Moeis Hospital) went smoothly. Mayor of Samarinda H. Syaharie Ja'ang appreciated and reviewed the activities of Hand Sanitizer making at STIKES Samarinda campus.
\end{abstract}

\begin{abstract}
Abstrak
Akibat wabah pandemi COVID-19 ketersediaan produk pencuci tangan di Kota Samarinda menjadi barang langka. Tujuan kegiatan ini yaitu melakukan upaya pencegahan COVID-19 melalui penggunaan Hand Sanitizer. Metode pada pengabdian ini meliputi beberapa tahap yaitu persiapan yang meliputi penyiapan alat dan bahan, proses produksi dengan tahapan pencampuran bahan-bahan menjadi produk hand sanitizer, dan proses pengemasan yaitu memasukan hand sanitizer yang sudah jadi ke dalam botol-botol kecil berukuran $20 \mathrm{ml}, 100 \mathrm{ml}$ maupun Dirigen $5 \mathrm{~L}$, serta labelling merek hand sanitizer, dan selanjutnya proses pendistribusian di RT 27, 28, 29 dan 30 Kelurahan Air Hitam. Civitas Akademika STIKES Samarinda (STIKSAM) dan Ikatan Keluarga Alumni (IKA STIKSAM) membuat hand sanitizer sesuai ketentuan WHO, proses pendistribusian hand sanitizer di wilayah RT 27, RT 28, RT 29 dan RT 30 Kelurahan Air Hitam dan Rumah sakit rujukan COVID-19 (RSUD AW. Sjahranie dan RSUD I.A. Moeis) berjalan dengan lancar. WaliKota Samarinda H. Syaharie Ja'ang mengapresiasi dan meninjau kegiatan pembuatan Hand Sanitizer di kampus STIKES Samarinda.
\end{abstract}

(C) 2021 Author(s)

Keywords: Handsanitizer; Pandemi COVID-19; Production.

${ }^{*}$ Corresponding author:
E-mail address: eka8382@gmail.com (Eka Siswanto Syamsul) 
https://doi.org/10.35877/454RI.mattawang338

\section{Pendahuluan}

Setiap harinya mikroorganisme virus, bakteri dan jamur menempel pada tangan melalui kontak fisik dengan lingkungan dan diantaranya dapat menyebabkan berbagai penyakit. Mikroorganisme ini perlu dimusnahkan atau dicegah penyebarannya, salah satu cara yang paling mudah dan tepat adalah dengan cara mencuci tangan menggunakan sabun dan air bersih yang mengalir, dapat juga digunakan sediaan pembersih tangan yang berbasis alkohol atau mengandung antibakteri yang dikenal dengan handsanitizer bila air bersih tidak tersedia (Wahyono, 2010). Virus Covid19 menyebabkan kepanikan di masyarakat Indonesia. Mudahnya penyebaran virus ini membuat masyarakat menggunakan masker sebagai cara berjaga-jaga, menggunakan sarung tangan dan pembersih tangan setiap hari(Saadat dkk., 2020).

Pembersih tangan berbasis alkohol yang direkomendasikan World Health Organization (WHO) yang sering digunakan, terutama terbuat dari etanol, isopropil alkohol, hidrogen peroksida kombinasi yang berbeda (Mahmood, dkk 2020). Penggunaan hand sanitizer sangat efektif ketika jauh dari tempat cuci tangan, kesulitan mencari air bersih dan sedang bepergian (Srikartika, Suharti, \& Anas, 2016). Mencegah bertambahnya mikroorganisme pada permukaan tubuh dan efektif membunuh kuman dengan penggunaan hand sanitizer (Desiyanto \& Djannah, 2013).

STIKES Samarinda (STIKSAM) merupakan perguruan tinggi kesehatan di Samarinda yang terdiri dari dosen, tenaga kependidikan, dan mahasiswa tidak hanya berkewajiban mendidik mahasiswa, tetapi juga memberikan kontribusi terhadap kesejahteraan masyarakat di sekitarnya. Wabah pandemic covid 19 memerlukan adanya peran nyata dari STIKSAM untuk turut berpartisipasi dan berkolaborasi dalam upaya penanganan penyebaran COVID-19. Pada dasarnya perlu usaha preventif yang harus dilakukan mengingat bahwa wabah ini tidak bisa dianggap sebagai pandemi biasa. Untuk mengkoordinir usaha tersebut. STIKSAM melalui Lembaga Penelitian dan Pengabdian Masyarakat (LPPM) mengambil langkah sesuai keilmuan Farmasi yang kami miliki yaitu dengan pembuatan hand sanitizer dan mendistribusikan kepada masyarakat sekitar kampus di RT 27, 28 dan 29 Kelurahan Air Hitam Kota Samarinda. Ketersediaan produk pencuci tangan menjadi barang langka di tengah ancaman pandemi COVID-19 terutama di Kota Samarinda. Meningkatnya pembelian masyarakat untuk barang-barang tersebut menjadi alasan kelangkaan. Bahkan tenaga medis pada saat ini pun kekurangan peralatan tersebut.

Tangan adalah anugrah dari tuhan untuk kita umat manusia, tangan merupakan organ tubuh yang sering digunakan untuk menyentuh sehingga terjadi penyebaran kuman, virus serta bakteri yang berbahaya. Aktivitas yang dilakukan seperti berjabat tangan, membuka pintu, memegang tangga, maupun mengetik komputer. Tanpa kita sadari, setelah kita makan, minum, mengusap mata, memegang hidung atau mulut, saat itulah kuman atau virus dapat masuk ke tubuh kita.

Pandemi Corona Virus Disease (COVID)-19 diseluruh Dunia termasuk Indonesia terutama Kota Samarinda telah menyebabkan langkanya Hand Sanitizer, karena banyaknya orang yang membutuhkan karena lebih praktis. Kita mengetahui salah satu cara memutus penyebaran virus SARS-CoV-2 penyebab COVID-19 memang adalah dengan mencuci tangan dengan kerap karena virus sangat mungkin menular melalui tangan yang tertempeli virus, yang mungkin diperoleh dari lingkungan yang tercemar virus.

Mengingat hal tersebut STIKSAM membuat hand sanitizer sesuai formula WHO dan sesuai edaran BPOM. Hand sanitizer produksi STIKSAM saat ini telah didistribusikan kepada para masyarakat yang berada di sekitar kampus yaitu kelurahan Air Hitam yang bekerjasama dengan IKA STIKSAM. Harapan selanjutnya pandemi Covid- 19 ini tidak menyebar luas dan dapat segera berakhir. Adapun tujuan yang ingin dicapai dalam kegiatan ini adalah melakukan upaya pencegahan COVID-19 melalui penggunaan Hand Sanitizer. Harapan dari kegiatan ini bisa bermanfaat bagi masyarakat luas dan Rumah sakit rujukan COVID-19 Kota Samarinda (RSUD AW. Sjahranie dan RSUD I.A. Moeis) dalam upaya pencegahan COVID-19. WaliKota Samarinda H. Syaharie Ja'ang mengapresiasi dan meninjau kegiatan pembuatan Hand Sanitizer di kampus STIKES Samarinda, beliau melihat kegiatan sosial dan donasi ini sangat bermanfaat bagi masyarakat dan Rumah sakit sebagai ujung tombak dalam penanggulangan COVID-19. Beliau berharap masyarakat untuk bias menerapkan Pola Hidup Bersih dan Sehat (PHBS) dan tetap produktif melalui Work From Home (WFH). 


\section{Metode}

Adapun waktu dan tempat pelaksanaan dilaksanakan pada tanggal 30 maret sampai 2 April 2020. tempat kegiatan produksi yaitu Laboratorium teknologi farmasi STIKSAM (30-31 Maret 2020) penyaluran tanggal 1-2 April 2020. Teknik yang digunakan yaitu sosialisai pembuatan terlebih dahulu kepada teman sejawat (dosen, tenaga kependidikan, mahasiswa dan alumni aktif), kemudian pelaksanaan proses produksi hand sanitizer. Adapun sasaran dalam kegiatan ini adalah masyarakat yang berada disekitar kampus yakni RT 27, RT 28, RT 29 dan RT 30 Kelurahan Air Hitam serta Rumah sakit rujukan COVID-19 Kota Samarinda (RSUD AW. Sjahranie dan RSUD I.A. Moeis).

Hand sanitizer merupakan pembersih tangan yang punya kemampuan antimikroba (untuk hambat atau bunuh bakteri atau virus) terdapat dua HS yaitu bentuk gel atau spray. Menurut rekomendasi Center For Desease Control and Prevention (CDCP) Amerika bahwa kadar alkohol efektif antimikroba 60-95\%, jika tidak sesuai Takaran maka HS yang dibuat menjadi tidak efektif. WHO membagikan 2 Formulasi yang direkomendasikan untuk diproduksi secara lokal, untuk memastikan keamanan dalam proses produksi dan penyimpanan, namun ketelitian dan ketepatan dalam penimbangan dan proses produksi menjadi perhatian agar konsentrasi akhir sediaan HS sesuai yang diinginkan.

Pada kegiatan ini STIKSAM memproduksi Hand sanitizer sesuai Formulasi pertama yaitu: Untuk membuat Handsanitizer konsentrasi akhir etanol $80 \% \mathrm{v} / \mathrm{v}$, gliserol $1,45 \% \mathrm{v} / \mathrm{v}$, hidrogen peroksida $(\mathrm{H} 2 \mathrm{O} 2) 0,125 \% \mathrm{v} / \mathrm{v}$. Prosedurnya dengan menuangkan ke dalam labu ukur berukuran $1.000 \mathrm{~mL}$ : etanol 96\% v/v sebanyak 833,3 mL, H2O2 $3 \%$ sebanyak $41,7 \mathrm{~mL}$, gliserol $98 \%$ sebanyak $14,5 \mathrm{~mL}$. Setelah itu, isilah labu hingga tepat $1000 \mathrm{~mL}$ dengan air suling, atau air rebus dan didinginkan. Kocok labu perlahan, hingga semua komponen tercampur rata, masuk dalam botol wadah sesuai dengan takaran yang disediakan.

\section{Hasil dan Diskusi}

Kegiatan pengabdian telah selesai dilaksanakan sesuai beberapa tahap meliputi: Pertama roses produksi Hand Sanitizer (merujuk pada edaran WHO dan BPOM). Pada tahap ini para tim pembuatan hand sanitzer diberikan sosialisasi terlebih dahulu mengenai cara pembuatan hand sanitizer tersebut. Semua tim sangat antusias dalam melakukan kegiatan ini.2) Tahap berikutnya yaitu teknik pelaksanaan, teknik yang digunakan dalam proses pembuatan yaitu sebagai berikut : Bahan-bahan untuk membuat sesuai dengan WHO/ edaran BPOM Cara membuatnya adalah dengan menuangkan ke dalam labu ukur berukuran 1.000 mililiter: etanol 96\%v/v sebanyak $833,3 \mathrm{~mL}, \mathrm{H} 2 \mathrm{O} 23 \%$ sebanyak 41,7 mL, gliserol 98\% sebanyak 14,5 mL. Setelah itu, isilah labu hingga tepat 1000 $\mathrm{mL}$ dengan air suling, atau air yang telah direbus dan didinginkan. Kocok labu secara perlahan, hingga semua komponen tercampur rata. 3) Setelah proses produksi selesai, selanjutnya pengepakan hand sanitizer ke dalam botol spray ukuran $20 \mathrm{ml}$ sebanyak 500 botol, kemasan $100 \mathrm{ml} 40$ Botol dan 20 Liter (4 dirigen@5 Liter) serta diberi label/merek sesuai dengan nama institusi yaitu STIKSAM, dan 4) Proses pendistribusian kelurahan Air hitam (sekitar kampus) serta Rumah sakit rujukan COVID-19 Kota Samarinda (RSUD AW. Sjahranie dan RSUD I.A. Moeis).

Pada proses Produksi ada kunjungan dadakan dari Bapak H. Syaharie Jaang, SH, M.Si (WaliKota Samarinda) ke Kampus Stikes Samarinda didampingi bapak H.M. Faisal, S.Sos, M.Si (Kepala Dinas Perindustrian Kota Samarinda), dan Kepala BPBD Kota Samarinda.
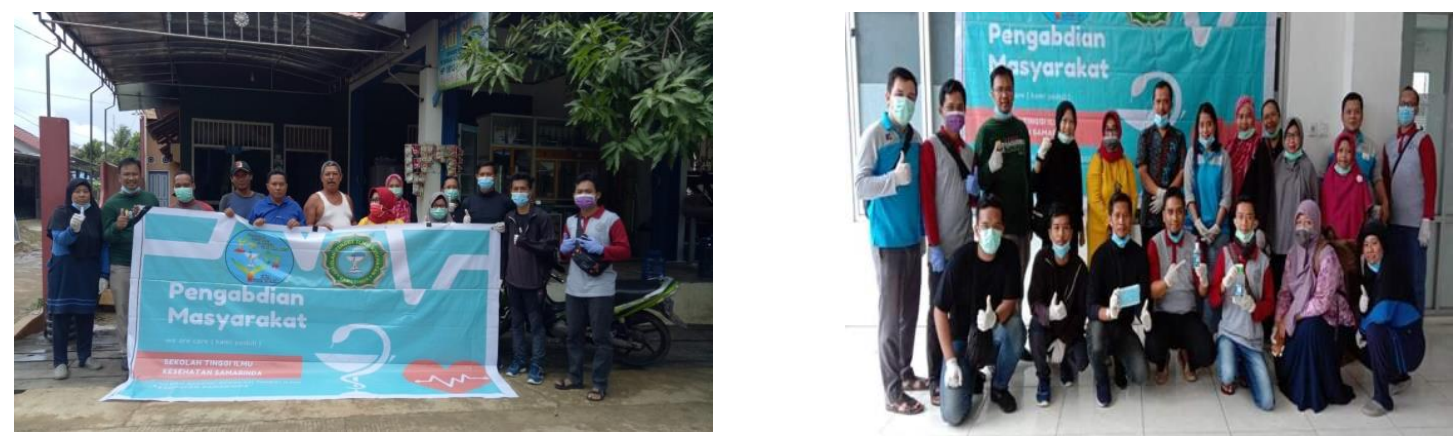

Fig. 1. Pembagian Hand Sanitizer di kelurahan Air Hitam (sekitar Kampus), bersama lurah Air Hitam Hj. Nuraida (ditengah baju kuning) 

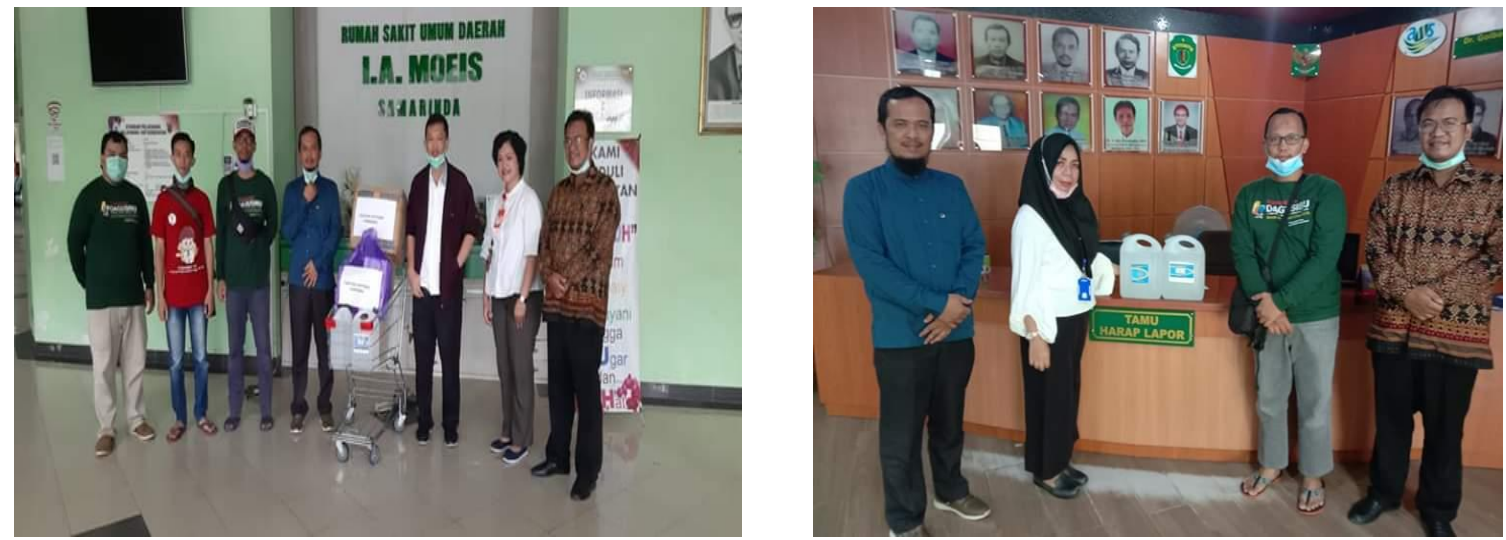

Fig. 2. Penyerahan Hand Sanitizer dan Alat Pelindung Diri (APD) di RSUD AW. Sjahranie dan RSUD I.A. Moeis

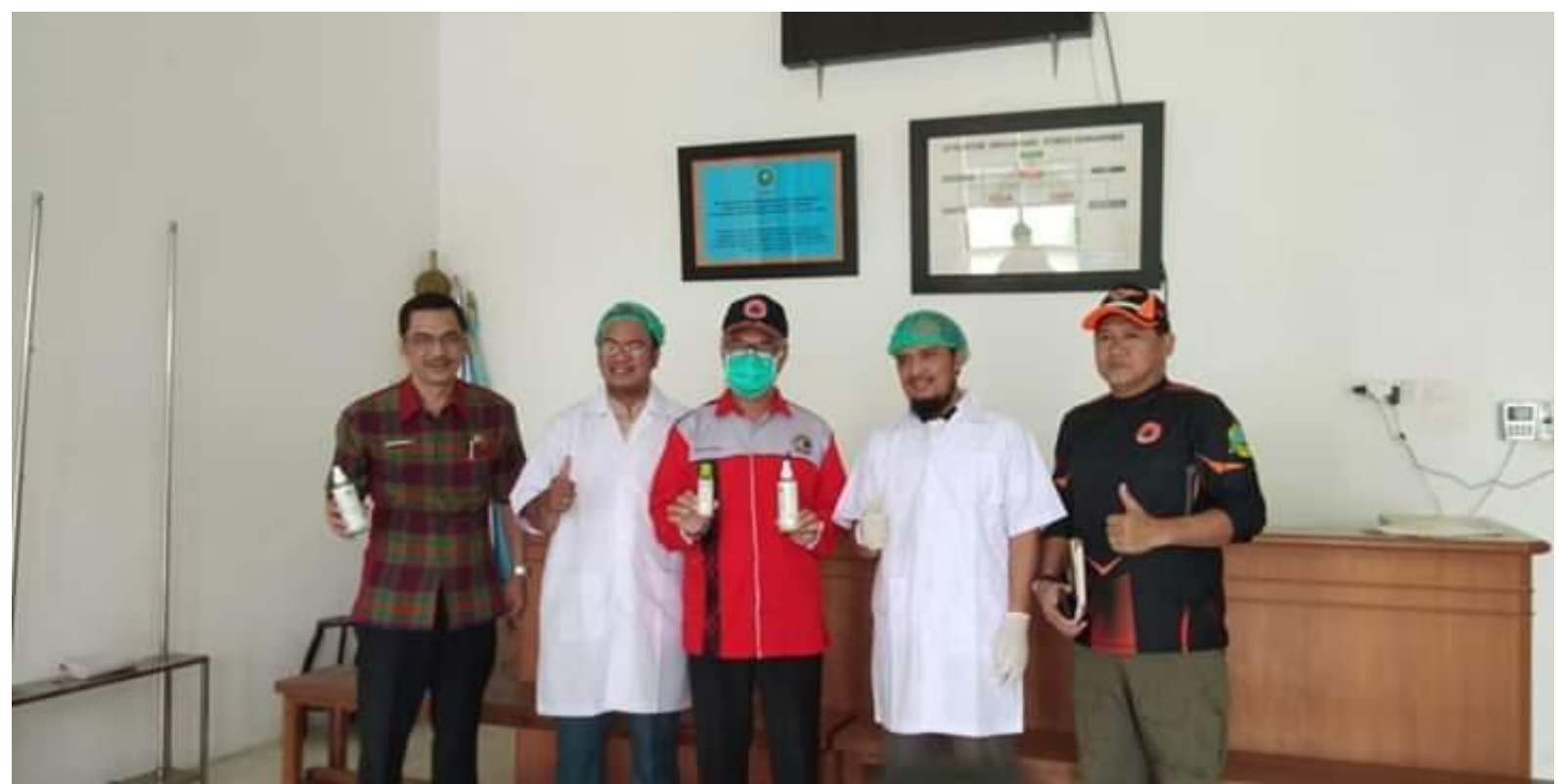

Fig. 3. Kunjungan Bapak H. Syaharie Jaang, SH, M.Si (WaliKota Samarinda) (ditengah baju merah) ke Kampus Stikes Samarinda saat meninjau pembuatan Hand Sanitizer

\section{Kesimpulan}

Kegiatan pengabdian pembuatan handsanitizer memberikan pengetahuan dan aplikasi praktis kepada civitas akademika STIKSAM (dosen, tendik, mahasiswa dan Alumni), untuk berkontribusi bagi masyarakat dan rumah sakit sebagai salah satu upaya pencegahan COVID-19.

\section{Acknowledgements}

Terimakasih banyak kepada Ketua STIKSAM atas bantuan dana pengabdian masyarakat, Ibu Lurah Kelurahan Air Hitam, Ketua RT 2 7, 28, $29 \& 30$ Kelurahan Air Hitam dan IKA Alumni STIKSAM yang telah mendukung kegiatan Pengabdian Masyarakat. 


\section{References}

Block S. 2001. Disinfection, Sterilization and Preservation. 4th. Edition. Williams and Wilkins.

Desiyanto, F. A., \& Djannah, S. N. (2013). Efektivitas Mencuci Tangan Menggunakan Cairan Pembersih Tangan Antiseptik (Hand Sanitizer) Terhadap Jumlah Angka Kuman. Jurnal Kesehatan Masyarakat, 7(2), 75-82. https://doi.org/10.12928/kesmas.v7i2.1041

Mahmood, A., Eqan, M., Pervez, S., Alghamdi, H. A., Tabinda, A. B., Yasar, A., ... \& Pugazhendhi, A. (2020). COVID-19 and frequent use of hand sanitizers; human health and environmental hazards.Science of The Total Environment,742, 140561. https://doi.org/10.1016/j.scitotenv.2020.140561

Srikartika, P., Suharti, N., \& Anas, E. (2016). Kemampuan Daya Hambat Bahan Aktif Beberapa Merek Dagang Handsanitizer terhadap Pertumbuhan Staphylococcus aureus. Jurnal Kesehatan Andalas, 5(3)540-545. https://doi.org/10.25077/jka.v5i3.613

Saadat, S., Rawtani, D., \& Hussain, C. M. (2020). Environmental perspective of COVID-19. Science of The Total Environment, 138870. https://doi.org/10.1016/j.scitotenv.2020.138870

Wahyono, S., Widanarko, S., Moersidik, S. S., \& Djajadiningrat, S. T. (2012). Metabolisme Pengelolaan Sampah Organik Melalui Teknologi Komposting Di Wilayah Internal Perkotaan. Jurnal Teknologi Lingkungan,13(2), 179-192

Yuliana, 2020.Corona Virus Diseases (Covid) sebagai tinjauan literatur. Wellines and Healthy Magazine,2(1) , p 187192. 